\title{
SPRAWOZDANIE Z DZIAŁALNOŚCI MIĘDZYWYDZIAŁOWEJ KATEDRY TEOLOGII KATOLICKIEJ UNIWERSYTETU W BIAŁYMSTOKU W ROKU AKADEMICKIM 2006/2007
}

W rok akademicki 2006/2007 Międzywydziałowa Katedra Teologii Katolickiej (MKTK), realizując swe statutowe zadania, weszła z gotowym, wcześniej przygotowanym na spotkaniach roboczych, planem pracy, obejmującym, obok badań własnych jej pracowników, realizację zasadniczego swego celu, mianowicie propagowania nauk teologicznych poprzez organizowanie we własnym zakresie, lub w kooperacji z innymi jednostkami naukowymi regionu, konferencji, sympozjów, sesji i zjazdów naukowych.

Stosując się do powyższych założeń Katedra Teologii Katolickiej UwB wespół z Katedrą Polityki Ekonomicznej Wyższej Szkoły Ekonomicznej (WSE) zorganizowała i przeprowadziła w dniach 11-12 września 2006 roku w Augustowie ogólnopolską konferencję naukową pod ogólnym hasłem „Małżeństwo - etyka - ekonomia”. Patronat honorowy nad całością przedsięwzięcia objął Metropolita Białostocki i Wojewoda Podlaski. Konferencja w zamierzeniu organizatorów była trzecią edycją, organizowanych przez wyżej wspomniane jednostki, zjazdów naukowych, które stanowiły, stanowią i zapewne stanowić będą płaszczyznę do gromadzenia, porządkowania i oceny wiedzy na temat człowieka (konferencja: „Człowiek - etyka - ekonomia” - 2002), rodziny (konferencja: „Rodzina - etyka - ekonomia” - 2004) i małżeństwa w warunkach współczesnego świata. Zasadniczym celem konferencji tegorocznej była refleksja i określenie najpoważniejszych współczesnych problemów związanych z zawieraniem i funkcjonowaniem małżeństwa oraz sformułowanie na tej podstawie wniosków skierowanych do podmiotów realizujących politykę rodzinną w Polsce zarówno na szczeblu samorządowym, jak i na forum rządowym.

W toku dwudniowych obrad referaty wygłosili m.in. wszyscy pracownicy MKTK, podejmując poszczególne problemy z punktu widzenia dyscyplin naukowych, które reprezentują. Sesję pierwszą rozpoczął kierownik Katedry Teologii Katolickiej, bp prof. dr hab. Edward Ozorowski referatem „Ontyczne podstawy małżeństwa”. W tej samej sesji naukową refleksją na temat małżeństwa podzielił się ks. prof. dr hab. Józef Zabielski podejmując temat „Etyczne «osłony» małżeństwa”. W sesji popołudniowej referat na temat „Miłość małżeńska” wygłosił ks. dr Andrzej Proniewski. W drugim dniu obrad w sesji przedpołudniowej w referacie „Pedagogizacja narzeczonych i małżonków” głos zabrał ks. dr hab. Adam Skreczko oraz ks. dr Tadeusz Kasabuła, który wygłosił referat 
pt. „Model małżeństwa na ziemiach polskich w XIX wieku”. W wyniku dwudniowych, ujętych w pięć sesji, rozważań zauważono i podkreślono, że w naukach społecznych i w polityce małżeństwo oraz całokształt życia rodzinnego ciągle nie znajdują optymalnej pozycji. Ponadto stwierdzono wyraźnie, że zaangażowanie nauki i praktyki powinno w większym stopniu przyczyniać się do integracji społecznej, zarówno w skali państwa, jak i w wymiarze indywidualnym. Wszystkie wygłoszone teksty ukazały się drukiem w publikacji Matżeństwo Etyka Ekonomia zredagowanej przez bp. prof. Edwarda Ozorowskiego i prof. Ryszarda Horodeńskiego, wydanej w roku 2007 przez Wydawnictwo Wyższej Szkoły Ekonomicznej w Białymstoku.

Sformułowane w formie pytania hasło: „Wychowanie - ale jakie?” było inspiracją konferencji naukowej, którą w dniach 25-27 października 2006 roku zorganizowała Katedra Teologii Katolickiej w kooperacji z Wydziałem Psychologii i Pedagogiki UwB. Ze strony Katedry ryzyko odpowiedzi na tak sformułowany problem podjęli: jej kierownik abp E. Ozorowski oraz ks. dr hab. A. Skreczko, jak i ks. dr A. Proniewski. Dnia 25 października referat na temat „Osoba jako podstawowa kategoria wychowania” wygłosił ks. Arcybiskup. Swoje rozważania osnuł wokół stwierdzenia, iż „w świecie współczesnym poszerzają się szybko obszary niejasnej koncepcji osoby, w następstwie czego kruszą się fundamenty etyczne życia ludzkiego", by na zakończenie swego wystąpienia skonkludować, że „człowiek najbardziej realizuje się jako osoba w miłości”. Dnia następnego (26 października) ks. Skreczko rozwodził się nad problemem związanym z ryzykiem wychowania, które to hasło postawił jako tytuł swego wystąpienia (referat pt. „Ryzyko wychowania”). Prelegent podkreślił tu prawdę podstawową, stwierdzając, iż działalność wychowawcy zawsze naznaczona jest ryzykiem, ponieważ ,jego propozycja skierowana jest do wolności wychowanka, który może ją przyjąć, albo odrzucić". $Z$ drugiej strony - jak stwierdził mówca - nie wolno zapominać, że ,jeśli koncepcja widzenia rzeczywistości wychowawcy jest błędna, to wartość całego procesu wychowania staje pod znakiem zapytania”. Trzeciego dnia konferencji bogactwem swych przemyśleń $\mathrm{w}$ referacie zatytułowanym „Funkcja wychowawcza rodziny w świetle Katechizmu Kościoła Katolickiego" podzielił się ks. Proniewski. Ze strony Wydziału powyższe refleksje uzupełnili i poszerzyli o świecki punkt widzenia: rektor UwB prof. dr hab. Jerzy Nikitorowicz w referacie „Tożsamość jako twórczy wysiłek podmiotu” (25 października), prof. dr hab. Rafał Piwowarski w wystąpieniu zatytułowanym: „Pozaszkolne uwarunkowania osiągnięć edukacyjnych uczniów" (26 października) i prof. dr hab. Jadwiga Izdebska, która wygłosiła referat pt. „Wychowanie rozumiane jako pomoc $\mathrm{w}$ wychowaniu dzieci i młodzieży. Potrzeba współdziałania środowisk wychowawczych" (27 października). Trzydniowa konferencja odbyła się w auli Wydziału Psychologii i Pedagogiki UwB w godzinach wieczornych. Miernikiem zainteresowania podjętą problematyką była pełna sala oraz ożywiona dyskusja 
po każdym z wystąpień. Wzięli w niej udział także, zachęcani do aktywności, dość licznie zgromadzeni studenci i nieliczne osoby postronne.

Zagadnienie równowagi między potrzebą autorytetu i sprawnej władzy a wolnością obywatelską było motywem przewodnim Warsztatów Filozofii Politycznej przebiegających pod hasłem „Wolność i tolerancja” zorganizowanych pod auspicjami Grupy Europejskiej Partii Ludowej i Europejskich Demokratów Parlamentu Europejskiego. W organizację i przebieg Warsztatów obok Wyższej Szkoły Administracji Publicznej (WSAP) w Białymstoku i Towarzystwa Naukowego Warszawskiego, włączyła się Międzywydziałowa Katedra Teologii Katolickiej. Warsztaty, które faktycznie były konferencją naukową, odbyły się w dniach 9-10 listopada 2006 roku w gmachu WSAP. Potencjał intelektualny Katedry $w$ tej dziedzinie zaprezentowali $w$ swych wystąpieniach jej pracownicy naukowi: ks. prof. dr hab. Józef Zabielski, który pierwszego dnia (9 listopada) podczas pierwszej sesji wygłosił referat pt. „Wolność jako wyznacznik moralności i jej zagrożenia" oraz w drugim dniu konferencji (10 listopada) w sesji czwartej ks. dr A. Proniewski, który usiłował dać odpowiedź na pytanie postawione w tytule swego wystąpienia: „Czy możliwa jest wolność bez Boga?” i ks. prof. dr hab. A. Skreczko, prezentując tekst referatu zatytułowanego „Wolność jako zadanie wychowawcze”. Ponieważ organizatorzy postanowili szukać rozwiązań wychodząc od pojęć fundamentalnych dla zagadnienia wolności, siłą rzeczy sięgnęli po argumentację, którą dostarczyć mogły jedynie nauki filozoficzne i teologiczne oraz do tej wizji rzeczywistości, w której kluczowymi pojęciami są ewolucja i samoorganizacja. Waga wystąpień prelegentów prezentujących chrześcijański, katolicki punkt widzenia była nie do przecenienia. Wynikiem dwudniowych "manewrów” intelektualnych był wniosek, który w podsumowaniu konferencji sformułowała rektor WSAP prof. dr hab. Barbara Kudrycka. Stwierdziła m.in., że „Wolność to nie tylko prawo człowieka, ale także warunek nieodzowny samorodnego ładu społecznego, który ewolucyjnie wyłania się z dorobku pokoleń". Aktywny udział uczestników konferencji spoza grona prelegentów, zwłaszcza dość licznej reprezentacji studentów, był możliwy dzięki przeznaczeniu dużego limitu czasowego na dyskusję.

W dniach 7-10 grudnia 2006 roku, wzorem roku ubiegłego, pracownicy MKTK aktywnie włączyli się w organizację drugiej edycji Międzynarodowej Konferencji Naukowo-Szkoleniowej pod hasłem „Życiodajna śmierć”, poświęconej pamięci Elisabeth Kübler-Ross. Głównym organizatorem konferencji był Zakład Pielęgniarstwa Ogólnego Akademii Medycznej w Białymstoku, współorganizatorami zaś Katedra Teologii Katolickiej UwB, Polskie Towarzystwo Lekarskie Oddział Regionalny Białystok i Instytut Pielęgniarstwa PWSLiP w Łomży. Przeprowadzane od zeszłego roku tego typu konferencje w założeniu organizatorów mają stanowić głos w powszechnej dzisiaj dyskusji, skłaniającej do refleksji nad śmiercią i umieraniem. Uczestnicy dzielą się własnymi przemy- 
śleniami, wątpliwościami, rozterkami i dylematami natury moralnej, etycznej, ludzkiej. Ta różnorodność spojrzenia jest jednym z podstawowych walorów owych kilkudniowych spotkań. W drugim dniu konferencji (8 grudnia) sesję plenarną w sali Muzeum Podlaskiego otworzył i w jej problematykę wprowadził ks. abp E. Ozorowski metropolita białostocki, zaś referaty ze strony Katedry wygłosili: ks. J. Zabielski, który podjął temat „Wyzwalający charakter cierpienia i śmierci” oraz ks. A. Proniewski z referatem pt. „Teodramat w ludzkim cierpieniu". Ksiądz Zabielski problematykę swego wystąpienia określił już na wstępie, twierdząc, iż „cierpienie i śmierć są tymi doświadczeniami ludzkiej egzystencji, które łączą się ze smutkiem, zniewoleniem i końcem życia. Mimo to, mają też w sobie charakter wyzwalający nowe siły, motywacje i dobro". W swej refleksji podjął on ten problem „z zamiarem - jak stwierdził - wykazania, że śmierć i cierpienie mają też znaczenie «życiodajne». Taki charakter wspomnianych doświadczeń odnosi się zarówno do osób je przeżywających, jak też towarzyszących innym w cierpieniu i umieraniu”. Ksiądz Proniewski esencję swego wywodu wyłożył już we wstępnej części referatu, gdy stwierdził: „u podstaw rozumienia ludzkiego cierpienia leży tajemnica teodramatu Boga czyli odkupieńczego cierpienia Chrystusa. Tylko w jego świetle cierpienie człowieka może otrzymać pełne wyjaśnienie. Człowiek w chwilach cierpienia może zwracać się do Jezusa Chrystusa, złączyć swoje cierpienia z Jego męką i ofiarą. Wtedy też zostaje ogarnięty przez Chrystusa tajemnicą odkupienia”.

Tego samego dnia w Aula Magna Akademii Medycznej w Białymstoku o godz. $15.00 \mathrm{w}$ dyskusji „okrągłego stołu”, toczącej się na temat „Życiodajna śmierć”, w gronie siedmiu moderatorów prezentujących dziedziny wiedzy medycznej, filozoficznej i teologicznej zasiadł i katolicki punkt widzenia etyka zaprezentował ks. Zabielski. Czterodniowej refleksji naukowej towarzyszyły imprezy o charakterze popularnonaukowym i wydarzenia kulturalne. Pracownicy MKTK na stałe wpisali się w organizację tego cyklu zjazdów. Odbywają się one bowiem pod honorowym patronatem m.in. metropolity białostockiego abp. E. Ozorowskiego, który też znalazł się wraz z księżmi J. Zabielskim i A. Proniewskim w stałym 20-osobowym składzie Komitetu Naukowego konferencji.

Od 1999 roku, a więc od swego powstania, Katedra Teologii Katolickiej wzięła na siebie obowiązek organizowania dwóch dorocznych zjazdów naukowo-pastoralnych, popularnie zwanych „kolędowym” i „paschalnym”. Odbywane nieprzerwanie $\mathrm{w}$ archidiecezji $\mathrm{w}$ okresie powojennym stały się one trwałym elementem permanentnej formacji kapłanów i katechetów świeckich i zakonnych w zakresie wiedzy teologicznej i życia duchowego. Tegoroczny zjazd kolędowy o charakterze sesji naukowej pod hasłem „Przypatrzcie się bracia powołaniu waszemu” odbył się dnia 13 stycznia 2007 roku w sali kina „Ton” w Białymstoku. Spotkanie przy nadspodziewanie licznym udziale prezbiteratu archidiecezji, katechetów świeckich i alumnów białostockiego seminarium du- 
chownego rozpoczął i jego tematykę nakreślił abp E. Ozorowski. Stwierdził on m.in., iż „samo słowo "powołanie» stało się niemal sloganem i nie dociera do świadomości współczesnego człowieka, jednakże odnajdywanie sensu swojego życia i dróg, po których trzeba kroczyć w życiu, to problem wszystkich ludzi, także człowieka współczesnego". Na program sesji złożyły się dwa wystąpienia. Pierwszy w porządku chronologicznym referat pt. „Duszpasterskie wyzwania XXI wieku" wygłosił ks. prof. dr hab. Ryszard Kamiński, pracownik naukowy Katolickiego Uniwersytetu Lubelskiego. Prelegent podkreślił, iż „podstawową troską duszpasterstwa powinno być tworzenie środowisk chrześcijańskich, a nie tylko reforma instytucji kościelnych. (...) Duszpasterstwo XXI wieku powinno bardziej doceniać wspólnotowe formy przeżywania i realizowania chrześcijaństwa: ruchy, stowarzyszenia, małe wspólnoty, grupy powinny stawać się rozpowszechnioną formą przeżywania chrześcijańskiego powołania i związku z Kościołem”, „Jak współczesnym ludziom mówić o Kościele?” to tytuł drugiego referatu, który wygłosił pracownik naukowy Uniwersytetu Kardynała Stefana Wyszyńskiego w Warszawie, o. prof. dr hab. Jacek Salij (OP). By odpowiedzieć na pytanie postawione $\mathrm{w}$ tytule wystąpienia, prelegent ustosunkował się wpierw do zjawiska, które we współczesnym świecie jest często postrzegane, ale nie jest rozumiane. Poruszył zatem sprawę tzw. „kryzysu Kościoła” i wyjaśnił, iż „Kościół nie może przeżywać kryzysu, choćby dlatego, że Kościół w całym tego słowa znaczeniu to Jezus Chrystus. Jeśli się mówi, że Kościół przeżywa kryzys, to chce się wyrazić prawdę, że to my, ludzie, przeżywamy kryzys”. Uwieńczeniem obrad była ożywiona dyskusja.

Tegoroczna sesja naukowa (tzw. zjazd paschalny) zorganizowana przez MKTK dnia 14 kwietnia 2007 roku poświęcona była obchodom 15 rocznicy utworzenia archidiecezji i metropolii białostockiej i pod takim hasłem odbywały się jej obrady. Rozpoczęła się ona o godz. 9.00 Mszą św. dziękczynną, odprawioną przez metropolitę białostockiego abp. E. Ozorowskiego w katedrze białostockiej. Część poświęcona rozważaniom naukowym rozpoczęła się o godz. $10.00 \mathrm{w}$ sali kina „Ton”. Po krótkim wprowadzeniu ks. Arcybiskupa głos zabrał ks. dr Tadeusz Krahel - historyk Kościoła i wykładowca AWSD w Białymstoku, który zaprezentował referat pt. „Od Wileńskiej do Białostockiej Metropolii”. W 40-minutowym wystąpieniu omówił proces powstawania i rozwoju struktur administracyjnych Kościoła katolickiego na Białostocczyźnie po II wojnie światowej, którego zwieńczeniem było ustanowienie stałej organizacji kościelnej, najpierw w postaci diecezji białostockiej (1991), a później archidiecezji i metropolii (1992). Następnie głos zabrał ks. dr hab. Mieczysław Olszewski (AWSD w Białymstoku). Swoje wystąpienie poświęcił zagadnieniom duszpasterstwa w Kościele białostockim. W referacie zatytułowanym „Duszpasterstwo w 15-leciu Archidiecezji Białostockiej. Stan aktualny i oczekiwania" przedstawił on w sposób zwięzły rozwój struktur i inicjatyw duszpasterskich w minionym 15-leciu, po czym, 
odwołując się do potrzeb wiernych lokalnego Kościoła, określił postulaty, które owe potrzeby rodzą. Do najważniejszych zaliczył: konieczność zaktywizowania istniejących struktur duszpasterskich, potrzebę bardziej skutecznej koordynacji działań duszpasterskich oraz dowartościowania roli świeckich poprzez sprawne funkcjonowanie duszpasterstw środowiskowych i ciągłe aktywizowania istniejących stowarzyszeń religijnych, wspólnot i grup modlitewnych, które są siłą napędową tradycyjnego duszpasterstwa parafialnego. Po referacie i krótkiej dyskusji głos zabrał dyrektor Archiwum Archidiecezjalnego w Białymstoku ks. dr Adam Szot, który zwięźle zaprezentował zorganizowaną przez siebie w Holu Głównym Centrum Pastoralno-Administracyjnego wystawę planszową, obrazującą najważniejsze wydarzenia organizacyjne i duszpasterskie w archidiecezji białostockiej na przestrzeni ostatnich 15 lat. Sesję, która zgromadziła nadspodziewaną liczbę duchownych i świeckich zaangażowanych w różnoraki sposób w działalność duszpasterską, zakończył krótkim podsumowaniem i modlitwą ks. Arcybiskup.

Realizując wcześniejsze założenia związane $\mathrm{z}$ badaniami nad miejscem i funkcjonowaniem człowieka, małżeństwa i rodziny we współczesnym świecie, Katedra Teologii Katolickiej zorganizowała w dniach 13-15 maja 2007 roku, wespół z Wyższą Szkołą Ekonomiczną w Białymstoku, kolejną edycję ogólnopolskiej konferencji pod hasłem „Dziecko - etyka - ekonomia”. Obrady, w których wzięło udział 25 specjalistów, reprezentujących dziedziny wiedzy wprost lub pośrednio obejmujące zakres problematyki określonej tytułem zjazdu, odbyły się w sali konferencyjnej hotelu „Wojciech” k. Augustowa. Przebiegały one pod patronatem Rzecznika Praw Dziecka dr Ewy Sowińskiej. We wprowadzeniu do konferencji rektor WSE prof. dr hab. Zbigniew Ejsmont podkreślił zasadność organizowania tego rodzaju zjazdów. Zauważyl, iż „zmiany w liczebności i funkcjonowaniu współczesnej rodziny wynikają głównie z wymagań ekonomii i świeckiej etyki oraz przyczyniają się do zmniejszenia urodzeń i powstawania enklaw ubóstwa, blokującego możliwości równego rozwoju dzieci. Historia dowodzi, że postęp w zakresie wychowania i warunków materialnych życia dzieci osiągany jest przy stale pogłębiających się różnicach, nieraz o cechach patologicznych. Stąd uzasadnione jest pilne poszukiwanie dróg doskonalenia funkcjonowania najmłodszego pokolenia". W konferencji, wzorem lat ubiegłych, aktywny udział wzięli wszyscy pracownicy naukowo-dydaktyczni Katedry. Ich wystąpienia niemal w całości wypełniły pierwszą sesję. Bezpośrednio po otwarciu obrad referat pt. „Dziecko w aspekcie celu” wygłosił metropolita białostocki abp E. Ozorowski. Następnie ks. J. Zabielski zreferował temat „Aksjologiczny status dziecka w kontekście współczesnej kultury życia”. Pierwszą sesję obrad zamknął ks. A. Proniewski refleksją ujętą w referat pt. „Dziecięctwo naturalne i nadprzyrodzone". W sesji drugiej swymi przemyśleniami na temat relacji dziecko - media podzielił się w referacie pt. „Dziecko wobec zagroże- 
nia płynącego z mediów" ks. A. Skreczko. Następnego dnia (15 maja) wyniki swych badań zreferował ks. T. Kasabuła, który w referacie pt. „Status społeczny dziecka w Polsce w XVIII wieku” podjął się próby naszkicowania kontekstu historycznego omawianej problematyki. W toku dwudniowych obrad i dyskusji sformułowano wnioski oraz propozycje pod adresem rodzin, organizacji społecznych oraz instytucji rządowych i samorządowych, ukazujące szanse równego rozwoju intelektualnego i materialnego dzieci w aktualnych warunkach ekonomicznych Polski.

„Chrześcijańskie dziedzictwo duchowe narodów słowiańskich. Wokół kultur śródziemnomorskich. Język. Literatura. Kultura. Historia” to hasło międzynarodowej konferencji naukowej zorganizowanej wspólnym wysiłkiem jednostek naukowo-dydaktycznych Wydziału Filologicznego UwB (Zakładu Językoznawstwa Historycznego i Zakładu Literatury Oświecenia i Romantyzmu) oraz Międzywydziałowej Katedry Teologii Katolickiej i Międzywydziałowej Katedry Teologii Prawosławnej w dniach 17-19 maja 2007 roku. Konferencja przebiegała pod honorowym patronatem rektora UwB prof. dr. hab. Jerzego Nikitorowicza i była wkładem organizatorów w dzieło obchodów rocznicy 10-lecia istnienia Uniwersytetu. Obrady odbywały się w hotelu „Białowieski” w Białowieży. W konferencji wzięło udział blisko 100 językoznawców, literaturoznawców, etnologów, historyków i teologów z kilkudziesięciu ośrodków naukowych Polski, Rosji, Białorusi i Ukrainy. Z racji na wyjątkowo liczną obsadę zjazdu i różnorodność dyscyplin naukowych, obrady odbywały się w kilku sekcjach. Katedrę Teologii Katolickiej reprezentowali: metropolita białostocki abp E. Ozorowski, który podczas uroczystego otwarcia konferencji wprowadził w jej tematykę i wygłosił w sesji plenarnej referat pt. „Rzym i Konstantynopol jako dwa typy kultury europejskiej”, oraz księża: A. Skreczko (referat pt. „Wychowanie w rodzinie według św. Jana Chryzostoma”), A. Proniewski (referat pt. „Hermeneutyka teologiczna pierwszych wieków a tożsamość chrześcijan narodów słowiańskich") i T. Kasabuła (referat pt. „Misje wśród Słowian południowych jako narzędzie rywalizacji między Wschodem i Zachodem"). Teksty wszystkich wygłoszonych referatów zostaną wydane drukiem w obszernej publikacji, której powstanie planuje się na listopad 2008 roku.

Miniony rok sprawozdawczy był okresem prac organizacyjnych MKTK, mających na celu określenie nowej formuły i nadanie form organizacyjnych studium kształcenia i doskonalenia zawodowego katechetów, które w przyszłym roku akademickim zainauguruje swoją działalność jako Podyplomowe Studia Doskonalenia Katechetycznego. Celem Studiów jest umożliwienie absolwentom studiów teologicznych podnoszenie kwalifikacji katechetycznych i przygotowanie ich do podejmowania procedur awansu zawodowego nauczyciela. Założeniem tej formy kształcenia katechetów jest poszerzenie umiejętności dotyczących procesu nauczania, ze szczególnym uwzględnieniem najnowszych 
technik nauczania religii w szkole i podczas prowadzenia katechezy przy parafii oraz pomoc $\mathrm{w}$ nabyciu zdolności diagnozowania sytuacji problemowych, pojawiających się w procesie nauczania i wychowania. Podyplomowe Studia Doskonalenia Katechetycznego są przeznaczone dla katechetów świeckich, zakonnych i duchownych legitymujących się wykształceniem wyższym magisterskim teologicznym lub pedagogiczno-katechetycznym. Cykl studiów przewidziano na trzy semestry obejmujące 360 godzin zajęć, w tym 190 godzin wykładów, 160 godzin ćwiczeń i warsztatów oraz 10 godzin seminarium naukowego. Absolwenci uzyskają kompetencje wymagane przy ubieganiu się o awans zawodowy nauczyciela oraz otrzymają świadectwo ukończenia Studiów po zaliczeniu wszystkich zajęć przewidzianych ich programem i po przedstawieniu pracy dyplomowej. Troska o prawidłowy przebieg kształcenia spoczywa na kierowniku Studiów, powołanym przez Kierownika MKTK. Na stanowisko to, z zadaniem uruchomienia procesu dydaktycznego, został mianowany ks. A. Proniewski. Wykładowcami są, oprócz stałych pracowników naukowych UwB, osoby, którym zlecono zajęcia i zapraszani goście.

Pracownicy naukowi MKTK w ramach działalności dydaktycznej prowadzili w roku akademickim 2006/2007 wykłady, konwersatoria, ćwiczenia i seminaria naukowe na UwB i na innych uczelniach, uczestniczyli w konferencjach, sympozjach, sesjach i innych, mieszczących się w polu ich naukowych dociekań, zjazdach naukowych, prezentując tam wyniki badań własnych. Rezultatem badawczej aktywności pracowników MKTK są publikacje naukowe i popularnonaukowe zamieszczane w formie artykułów w czasopismach krajowych i o zasięgu międzynarodowym oraz monografie. W roku 2006 ukazała się, jako trzeci tom serii wydawniczej Rozprawy Międzywydziatowej Katedry Teologii Katolickiej, książka autorstwa ks. J. Zabielskiego pt. Wydobywanie dobra. Teologia chrześcijańskiego mitosierdzia, (Wydawnictwo UwB, Białystok 2006, s. 201) oraz w roku 2007 tom czwarty tejże serii - publikacja również autorstwa ks. Zabielskiego pt. Odpowiedzialność za życie (Wydawnictwo UwB, Białystok 2007, s. 253). Ksiądz A. Skreczko opublikował natomiast cykl artykułów popularnonaukowych o tematyce wychowania w rodzinie pt. Wychowanie domowe (Białystok 2007). W omawianym roku sprawozdawczym ukazał się kolejny, piąty tom czasopisma MKTK „Rocznik Teologii Katolickiej” (RTK), zawierający teksty pracowników Katedry oraz autorów współpracujących z RTK. Recenzję tego tomu dał bp prof. dr hab. Andrzej Dziuba.

Godnym odnotowania jest fakt, iż w roku 2007, na mocy decyzji Prezydenta Rzeczypospolitej Polskiej Lecha Kaczyńskiego, ks. dr hab. Józef Zabielski prof. UKSW i pracownik naukowy MKTK otrzymał tytuł profesora zwyczajnego, w związku z czym Katedra zatrudnia obecnie dwie osoby na stanowisku profesora zwyczajnego, jedną na stanowisku profesora nadzwyczajnego, dwie osoby na stanowisku adiunkta i jedną osobę w pionie administracyjnym. Aktywność 
naukową pracowników MKTK zauważają i doceniają władze uczelni, czego przejawem jest fakt, iż w roku 2006 ks. A. Skreczko otrzymał nagrodę za „pracę naukową i działalność organizacyjną” oraz Srebrny Krzyż Zasługi za „wzorowo sumienne wykonywanie obowiązków wynikających z pracy zawodowej” (decyzja Prezydenta Rzeczypospolitej Polskiej z 4 grudnia 2006 roku).

Efektywnemu funkcjonowaniu MKTK sprzyjają comiesięczne robocze spotkania jej pracowników. Umożliwiają one koordynację badań własnych i statutowych Katedry oraz służą zgłaszaniu i opracowywaniu projektów prac badawczych i dydaktycznych. Każdorazowe spotkanie jest przygotowane i prowadzone przez kierownika Katedry abp. E. Ozorowskiego i przebiega według ustalonego przezeń porządku.

Ks. Tadeusz Kasabuła

Uniwersytet $w$ Białymstoku 